\title{
La formación del Profesor en Historia en la Provincia de Buenos Aires,
}

1990-2010

por Carlos Alberto Dicroce

CISH - IdIHCS- Universidad Nacional de La Plata

cdicroce@infovia.com.ar

\section{Resumen}

En este trabajo abordamos algunos aspectos de la formación de profesores en Historia en los Institutos de Formación Docente, dependientes de la Dirección de Educación Superior de la provincia de Buenos Aires, en el período comprendido entre la transición democrática y el de la sanción de la nueva ley de Educación del año 2006 y sus consecuencias en la jurisdicción. Pondremos especial énfasis en el análisis crítico de los programas y diseños curriculares en la formación inicial; en las políticas provinciales de perfeccionamiento y actualización continuos y en la formulación de alternativas para la selección de profesores del área de las Ciencias Sociales y la Historia en las escuelas secundarias, atendiendo al reconocimiento de las trayectorias y evaluación de los docentes. Haremos un recorrido histórico durante estos últimos veinticinco años distinguiendo los contextos y escenarios que caracterizaron la formación del profesor de Historia para volver a pensar el sentido y las nuevas problemáticas de la profesión docente.

Palabras clave

Formación inicial del profesor de historia; reformas y cambios en la educación secundaria; enseñanza de la historia.

\section{$\cos$}

\section{Training teacher of History in the Province of Buenos Aires, 1990-2010}

\section{Abstract}

This article addresses some aspects of teacher training in History at the Teacher Training Institutes, of the Directorate of Higher Education in the Province of Buenos Aires, in the period of democratic transition and the enactment of the new Education Law in 2006 and its consequences in the jurisdiction. We will specially emphasize on critical analysis of programs and 
curriculum in the initial training in provincial policy development and continuous updating and formulation of alternatives for the selection of teachers in the area of Social Sciences and History in schools secondary schools, considering the recognition of pathways and evaluation of teachers. We will make a historic journey over the last twenty five years distinguishing the contexts and settings that characterized the history teacher training to rethink the meaning and the new problems of the teaching profession.

Keywords

Initial history teacher; reforms and changes in secondary education; history teaching.

"Muchos profesores nos encontramos diariamente ante la necesidad de reconstruir para los alumnos y para nosotros mismos un sentido que motorice la acción pedagógica." Alejo Stauber, orientador educacional de la Escuela Media no 1 , de La Plata

(Diario: El Día, La Plata, 6/3/2011)

\section{Introducción}

En el marco de la instancia provincial del Parlamento Juvenil del Mercosur —un espacio de debate estudiantil que, bajo el lema "Qué escuela secundaria queremos" — se llevó a cabo el 17 de Septiembre de 2010, en el anexo de la Cámara de Diputados de la legislatura de la provincia de Buenos Aires, organizado por la Dirección General de Cultura y Educación, alumnos de todas las regiones de la provincia opinaron sobre la "realidad educativa" que viven a diario. Una de las cuestiones que señala la crónica periodística y que contó con el consenso de los estudiantes allí reunidos, se refiere a "la vocación" y "formación de sus profesores" y a la calidad de los vínculos que los estudiantes mantienen con sus docentes. En la crónica, una alumna que cursa la Escuela Secundaria Básica se expresó de esta manera:

“Para mí, el problema más grave es que muchos profesores no nos saben tratar. ¿En qué sentido? No saben relacionarse, llegar a los alumnos, sobre todo cuando alguno necesita ayuda. ¿Por qué? Porque no están preparados. Y eso deriva en discriminación. Es por ello que planteamos el tema 'inclusión educativa' para tratar en el Parlamento". (Diario El Día, La Plata, 18/9/2010)

Mientras que otra de sus compañeras afirmó: "no hay códigos entre profesores y alumnos". En este contexto se les preguntó qué pedían ellos de un docente para ser respetado. "Que escuche a los jóvenes; empatía y comprensión; vocación y capacidad para enseñar”, enumeraron (...). "Es que quedan pocos profesores por vocación. Para muchos es un trabajo más; ese es el problema” (Diario El Día, La Plata, 18/9/2010). 